\title{
Article
}

\section{The Impact of COVID-19 on Electricity Demand Profiles: A Case Study of Selected Business Clients in Poland}

\author{
Marcin Malec ${ }^{1, *(\mathbb{D})}$, Grzegorz Kinelski ${ }^{2} \mathbb{D}$ and Marzena Czarnecka ${ }^{3} \mathbb{D}$ \\ 1 Division of Energy Economics, Mineral and Energy Economy Research Institute of the Polish Academy of \\ Sciences, ul. J. Wybickiego 7A, 31-261 Kraków, Poland \\ 2 Department of Management, Faculty of Applied Sciences, WSB University, ul. Cieplaka 1C, \\ 41-300 Dabrowa Gornicza, Poland; gkinelski@wsb.edu.pl \\ 3 Department of Law and Insurance, College of Finance, University of Economics Katowice, ul. 1 Maja 47, \\ 40-287 Katowice, Poland; marzena.czarnecka@ue.katowice.pl \\ * Correspondence: malec@min-pan.krakow.pl; Tel.: +48-12-617-1608
}

Citation: Malec, M.; Kinelski, G.; Czarnecka, M. The Impact of COVID-19 on Electricity Demand Profiles: A Case Study of Selected Business Clients in Poland. Energies 2021, 14, 5332. https://doi.org/ $10.3390 /$ en14175332

Academic Editor: Susan Krumdieck

Received: 26 July 2021

Accepted: 24 August 2021

Published: 27 August 2021

Publisher's Note: MDPI stays neutral with regard to jurisdictional claims in published maps and institutional affiliations.

Copyright: (c) 2021 by the authors. Licensee MDPI, Basel, Switzerland. This article is an open access article distributed under the terms and conditions of the Creative Commons Attribution (CC BY) license (https:// creativecommons.org/licenses/by/ $4.0 /)$.

\begin{abstract}
The COVID-19 pandemic has caused changes in electricity demand and, consequently, electricity consumption profiles. Given the rapid changes in energy prices, it is significant from the perspective of energy companies, and forecasting consumed energy volume. A necessity for accurate energy volume planning forces the need for analyzing consumers' behaviors during the pandemic, especially under lockdowns, to prepare for the possibility of another pandemic wave. Many business clients analyzed in the paper are economic entities functioning in sectors under restrictions. That is why analyzing the pandemic's impact on the change in energy consumption profiles and volume of these entities is particularly meaningful. The article analyzes the pandemic and restrictions' impact on the total change of energy consumption volume and demand profiles. The analysis was conducted basing on data collected from a Polish energy trading and sales company. It focused on the energy consumption of its corporate clients. Analyzed data included aggregated energy consumption volumes for all company's customers and key groups of economic entities under restrictions. The analysis demonstrates the influence of pandemic restrictions on energy consumption in the group of business clients. Significant differences are observable among various sectors of the economy. The research proves that the largest drops in energy consumption are related to shopping centers and offices. Altogether, the restrictions have caused a 15-23\% energy consumption drop during the first lockdown and a maximum $11 \%$ during the second against expected values.
\end{abstract}

Keywords: COVID-19 pandemic; lockdown; electricity demand profiles; energy consumption

\section{Introduction}

The outbreak of the COVID-19 pandemic in 2020 was unexpected and began many new challenges for the global and national economies [1]. The situation has significantly impacted numerous industries, including production, agriculture, transport, financial services, education, and healthcare [2]. Some of its consequences were changes in the electricity demand profiles of consumers representing various branches of the economy. Has the situation significantly impacted the energy sector, in which the correct forecasting of electricity consumption is one of the key factors guaranteeing power plants' stability works and continuous financial income? It concerns energy production, transfer, and supply [3,4]. The International Energy Agency (IEA) indicates that the change in energy demand in 2020 was the largest in the last 70 years. In 2020, the pandemic decreased the global GDP by $4.4 \%$. This value was significantly higher than the GDP decrease of $2009(0.1 \%)$ that resulted from the global economic crisis. Forecasts indicate that in 2021, global production will recover to the level of 2019 due to an economic boom in large developing countries, particularly China and India. However, it is expected that developed economies will not recover to the levels they had before the pandemic [5]. During the 
pandemic, in most countries, demand for electricity supply decreased significantly. It results in large uncertainty for all energy companies in the world. The pandemic makes predicting the situation's development impossible. Because of the lockdowns, limiting many life, economy, construction, and production activities decreased global demand for energy. Undeniably, the decrease has caused damage to the energy industry, which, in consequence, led at least nineteen American energy companies to bankruptcy [6].

Because of how the virus spreads, the main way to fight against it was to limit human interactions locally and globally. Depending on the country, the level of restrictions was related to an adopted strategy of fight against the pandemic and infection numbers [7]. One should pay attention to governments introducing restrictions undoubtedly influencing electricity consumption by consumers in many sectors. Unquestionably, politicians making decisions had taken energy security and the necessity for maintaining some economic sectors into account before restrictions were implemented. However, they did not know forecasts of possible consequences. Introducing restrictions usually had far-reaching consequences for energy companies. The lack of scenarios of restrictions' influence on energy consumption was significant in production planning and energy transfer organizing. However, the most severe consequences were observable in the electricity trade.

Introducing the first lockdown in March 2020 to respond to the SARS-CoV-2 spread was an entirely new situation for individual and business electricity consumers. In consequence, freezing many branches of the economy has led to considerable decreases in the first half of 2020 energy consumption. Compared to May 2019, energy consumption in 2020 was $8 \%$ lower [8].

Gradual unfreezing of the economy in the second half of 2020 caused successive equalization of energy consumption levels compared with the previous year. Sometimes, it was even higher than the year before. The rapid increase in 2020 energy consumption occurred in September. New restrictions of October-November 2020 did not change the increasing trend. At the beginning of December 2020, the electricity consumption level was circa (ca.) 14.5 TWh, 200 GWh more than in December $2019[9,10]$.

In this context, it is essential to learn how to operate in case of a crisis. It is necessary to consider and adjust to aspects of a crisis and restrictions imposed by law. More than that, there is a need to be aware that a similar situation may happen again. It may refer to possible waves of the pandemic as well as other crises potentially impacting energy consumption for different hours, situations, and various branches of the economy. The energy sector has to be prepared for such situations. That is why an analysis of electricity consumption profiles is an absolute necessity. Uncertainty also impacts investment decisions in the energy sector, which is another reason behind the need for analysis [11,12].

As mentioned, the energy sector situation was disturbing for energy trading companies that carry out transactions on the stock exchange $[13,14]$. Electricity prices on the commodity market are conditioned mostly by production and environmental costs [15]. They are also strongly related to fuel prices, in Poland, it still is coal [16].

Given the energy prices fluctuation on the wholesale market, an accurate forecast is essential for energy trading and sales companies $[17,18]$. An adequate assessment of energy demand in particular hours of the day allows for correcting a contract position at the right time, maximizing the company's benefits, and minimizing its losses [19]. A key challenge from the perspective of energy trading companies was the changes in the consumption schedules and deviations in consumers' profiles. That is why the analysis of consumed energy volumes may enable an appropriate reaction to adopt accurate coefficients correcting consumption schedules, dependent on imposed restrictions.

The article analyzes energy consumption by a particular group of customers of a national energy trading and sales company. The research is focused on the restrictions impact on the changes in electricity consumption volumes. Results were obtained through measurements taken during the lockdowns (the periods of limited mobility and activity of society) and compared with values obtained in the comparable period in 2019 and before the pandemic. The analysis concerns the total electricity consumption volumes and energy 
consumption profiles of clients from the key sectors. Besides the comparative analysis of energy consumption in 2019 and 2020, the article employs basic statistical measurements for the volatility analysis. Furthermore, the study includes the assessment of the ratio of expected to actual energy consumption based on trends from before the pandemic.

The remainder is organized as follows. Section 2 presents a review of current research on the influence of the COVID-19 pandemic on the energetic sector. Section 3 presents the schedule of introducing and lifting restrictions by the Polish government in 2020. Section 4 includes computing methodology. Section 5 includes results. Section 6 presents a discussion and the most important conclusions.

\section{Literature Review}

Undoubtedly, demand for electricity radically decreased during the lockdowns because governments have forced isolation and implemented numerous limitations on movement and transport. Consequently, the load structure and its daily profile have also changed, which was incredibly difficult for energy producers and sellers to balance. Changes have also been visible in national energy mixes. The share of energy produced from renewable resources has increased, while the total production of electricity has decreased [20]. The new situation in the balance of power and the increased uncertainty of demand have put pressure on system operators and caused problems with maintaining voltage in the power grid and other challenges for system management [21]. Thus, the pandemic has generated unprecedented distortions in almost every element of the energy market. In [22], it was proven that data on electricity markets with high granularity and frequency might be used for the causal estimation of the COVID-19 pandemic's shortterm influence on the economy by delivering information important for future lockdown politics [22].

The pandemic's impact on the European electricity markets has been immense, especially in countries with rich energy supplies and nearly non-existent marginal production costs, such as France. The author of [23] presented the quantitative assessment of the crisis's influence on the French electro-energetic sector. During the lockdown, France experienced an unprecedented decrease in demand $(-11.5 \%)$ and energy prices decline $(-40 \%)$, which caused losses for the market participants estimated at 1.2 bln $€(-45 \%)$ [23]. The COVID-19 pandemic's impact was also visible in decreasing GDP. For example, in Italy, it decreased about 30\% [22]. The change in primary energy consumption in 20 European countries with the highest GDP was also discussed in [24].

In 2020, the only huge economy with a higher demand for electricity was China. However, the $2 \%$ increase was much lower than the values from previous years of about $6.5 \%$. The other main electricity consumers, including the United States, India, Europe, Japan, South Korea, and South-Eastern Asia, noted a decrease in the scale of the whole year [1].

Nearly $42 \%$ of global demand for electricity is generated by industry and $22 \%$ by commercial and public services. That is why economic activity and electricity consumption are tightly related. In developed economies, the share of these sectors is more or less equal, about $32 \%$. In developing countries dominated by industry, this sector needs about half of the final demand, while services use about $14 \%$ [5].

An accurate assessment of energy demand fluctuation based on constantly updated data is urgently required to analyze changes in the energy sector, production planning, and energy transportation. It is because investments and global energy supply chains have been distorted [25]. Load curves, especially electricity consumption peaks, have also changed. Noticeable changes in demand (consumption) in the macro- and microeconomic levels presented in the body of literature include:

1. Short-term demand decreases when the restrictions are introduced [26], but it is expected that demand will gradually recover after lifting them [27]. 
2. The peak of electricity demand changes. Studies based on electricity consumption in Canada indicate that the highest demand before the pandemic was in the second half of the week (from Wednesday to Friday), while after the pandemic, it has been observed at the week's beginning (from Monday to Tuesday) [28].

3. Demand for electricity decreases in the morning peak [29].

4. A change in society's behavior is visible, e.g., in using public transport. A total of $56.3 \%$ of respondents have limited its usage during and after the COVID-19 pandemic [30].

5. Demand for electricity decreases in industry and commerce but increases in households [10].

In the body of literature, there are studies of the impact of the pandemic on electricity consumption in various groups of end-consumers based on real measurements. Such research was conducted among households' inhabitants, an important group of consumers, who have changed electricity demand during the pandemic [31]. Other similar works present studies of the COVID-19 pandemic's influence on household electricity consumption in China [32], Spain [33], and Canada [34].

The other analyzed sector was healthcare. In these studies, authors review various changes in healthcare in different countries and their impact on the energy sector and environment. They present conclusions on the impact of the COVID-19 pandemic on these three sectors regarding climate change and the change in environmental emissions to which also healthcare has contributed [35].

Undoubtedly, new practices and social behaviors acquired during the pandemic influenced the need for electricity and its consumption. It has been proven that even though general demand for electricity during the pandemic decreases, quantitative and time differences are complex, and the return to usual consumption in various regions is not equivalent [36].

Studies demonstrate that the pandemic has had a particular effect on commerce. Analyses of the retail trade indicate that in March and April 2020, the highest decreases in the European Union countries were noted for gasoline and commodities bought in department stores and shopping malls. The situation stabilized in June 2020. The second period of decrease was observed from November 2020 to January 2021 [37].

Studies $[5,27]$ indicate that changes in electricity consumption were independent of the region and the highest in commerce and services. The only difference was a period in which they occurred: the first quarter of 2020 - China; the second quarter of 2020Argentina (South America), Spain, and the United Kingdom (Europe); the second and the third quarter of 2020-the US (North America). Only in South America, the changes were also observed in the industry. Studies demonstrate that in the sector of households, significant changes in energy consumption were not noted in the analyzed regions.

Data presented in the European Parliament's report indicate that differences in the functioning of various industries were significant, which was another reason behind the change in their energy consumption. In EU countries, the results of the pandemic were primarily felt in the digital and healthcare sectors. The chemical industry, construction, and food production now go out of the crisis, which is best represented by the "V" curve, they recover to the production level before the pandemic. The automotive and textile industries are in a similar situation. Despite decreases, they are now recovering their positions before the first lockdowns. Sectors dependent on direct contact and human interactions, such as culture, environment, and air transport, have suffered from the crisis the most. They will be coping with its consequences for a long time. However, it has been proved that the pandemic increased the awareness of the benefits of digital and ecological transformation, which have to be associated with respective political investments and motivations [38].

Studies also indicate that from the perspective of the energy sector, the most direct consequences concerned the levels of power consumption, production mix structure, and electricity market price. Electricity consumption decreased by $15 \%$ in relation to previous years, and one could observe changing energy demand profiles in the states that introduced more rigorous restrictions than others, e.g., Italy, France, and Germany. In the states with 
less rigorous limitations (e.g., Sweden), significant changes in energy consumption were not noted [39]. In the context of the pandemic's influence on energy companies' functioning, particular attention deserves studies concerning the companies' financial outcomes [40]. Authors in [41] demonstrated that even though the lockdowns decreased mean energy prices in Italy by $45 \%$, the transmission costs increased by $73 \%$ for the analogous period from the previous years. Thus, investments in power grids and the development of demand management technology are indispensable. Simultaneously, the growing share of renewable energy sources may increase the costs of maintaining a reliable power grid [42]. The COVID-19 pandemic has negatively influenced energy production, causing a rapid drop in income. Companies did not regulate fixed costs and expenses, which led them to lose value [43]. As mentioned in the introduction, some were even forced to declare bankruptcy [6].

The number of works evaluating the impact of restrictions on energy consumption from the perspective of an energy trading and sales company, which produces, distributes, and sells energy, is still very low. Such studies were conducted in the context of the possibility of implementing additional enhancements to energy consumption forecasting tools $[44,45]$. Understanding the changes in electricity demand and their influence on forecasting consumption is essential for maintaining reliable power grid operation and realizing tasks of energy trading companies with the best possible financial outcome. The change of consumers' behavior during the pandemic negatively impacts the predictability of demand schedules, which is critical for energy trading companies.

\section{The Pandemic in Poland-A Course (Chronology)}

In Poland, the first restrictions resulting from the COVID-19 pandemic were introduced by the Regulation of the Minister of Health on the Announcement of the State of Epidemic Emergency on the Territory of the Republic of Poland dated 13 March 2020. In practice, the state of the epidemic has been functional in Poland since 20 March 2020, after amending the announcement [46].

The regulation issued on 13 March introduced restrictions related to the functioning of many activities. The list of restricted entities was provided in the regulation following the Polish Classification of Activity. The restrictions introduced in the first period were gradually tightened. Since 25 March, there was a ban on movement except for strictly defined cases. April 1 introduced a ban on the operation of cosmetic and hairdressing salons and additional limitations to commerce. Lifting them began on 20 April, though their first effects were visible on 4 May. Eventually, the first stage of restrictions ended on 6 June. Since then, some recommendations on personal protection have been maintained. The limitations from March and April were called a "hard lockdown."

Since 8 August, in the country, there were regional restrictions. The state was divided into "yellow" and "red" zones. Districts were classified into them based on the number of confirmed infections. The second period of significant restrictions began on 24 October, though more limitations were added two weeks later. Some of them were lifted on 27 November 2020. The third state of restrictions was called a "national quarantine" and began on 28 December 2020 (Figure 1). The authors analyzed the impact of the pandemic on the change of energy demand profiles in 2019 and 2020. That is why "national quarantine" restrictions implemented in 2021 are not discussed in this article. 


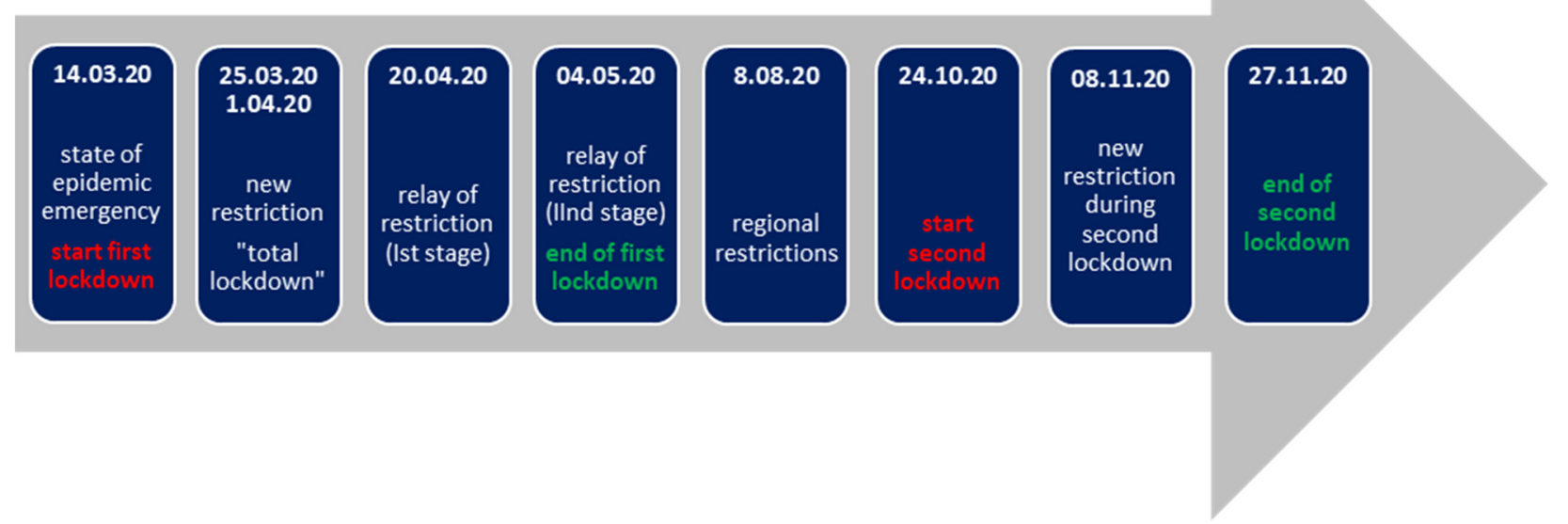

Figure 1. Graphical representation of COVID-19's restrictions from 2020 [46].

\section{Methodology and Data}

\subsection{Data Characteristics}

The analyzed dataset included the electricity consumption volumes of the customers of one of the national trading companies. The data were collected in hourly resolution for each hour in 2019 and 2020. The data were delivered in a day $n+2$ by the Balance Responsible Party (Administrator) based on data coming from the Distribution System Operator. In case of detecting measurement errors, the Balance Party and the Operator revised them within 2 following days (Figure 2).

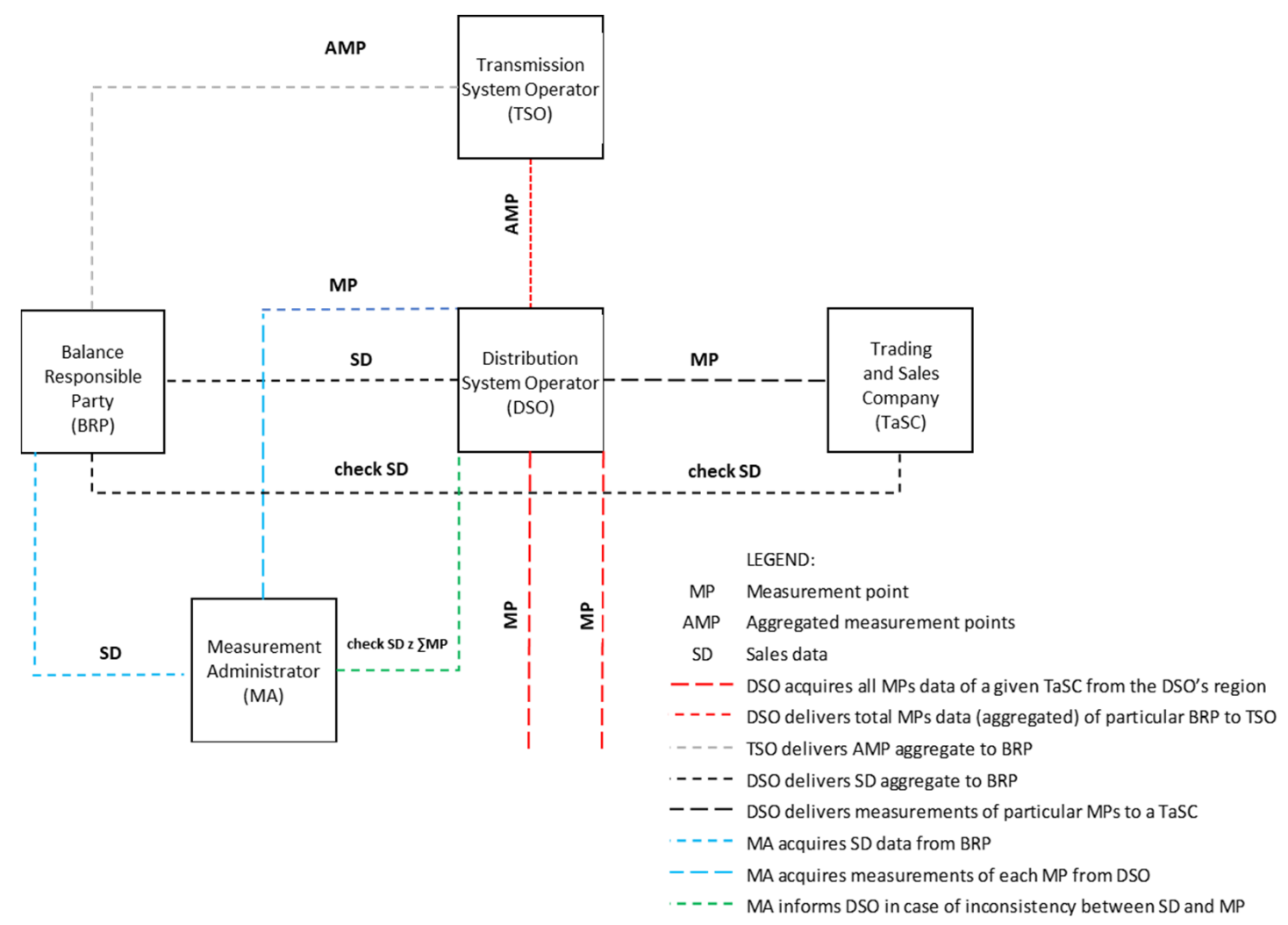

Figure 2. Collection and verification of measurement data-diagram. 
Consumers belonging to the analyzed set represented various economic entities, e.g., production, service, and commercial companies operating in the territory of the whole country. The biggest clients were, among others, companies producing and distributing electricity, gas, and steam, ca. 35\%, industrial consumers (food processing, electromechanical, and wood industries), ca. 30\%, real-estate market companies (e.g., shopping malls), ca. $15 \%$, and agriculture, ca. $7 \%$. The total volume of energy consumed in 2019 was ca. 1.65 GWh. The Balance Responsible Party was obliged to create aggregates, including measurement points indicated by the Trading and Sales Company. The balancing positions of clients or shopping groups were appointed based on these points, but after an energy trading and sales company creates an energy consumption schedule. Such a plan must include all situations that may affect energy consumption (a day of the week, days off, unusual days, and nontypical phenomena). Parallelly, a considerable hardship for trading companies was verification and possible plan corrections due to an inertia period lasting 3 days. Actual consumption data were published on day $n+2$ after 10:00, and SPOT trading on the Day-Ahead Market had to be submitted on the current day until 10:00 to the Polish Power Exchange.

The aim of the paper is to analyze the impact of the COVID-19 pandemic on the total electricity consumption and consumption profiles of clients representing key economic sectors. However, the authors are aware of certain limitations that may have an additional impact on energy consumption, such as the temperature difference occurring in the analyzed years or the difference in the level of companies' production. Due to measurement points' dispersion (several hundred recipients located in places of various longitude and latitude of Poland) and the lack of information about the production levels, introducing additional assumptions would adversely affect the presentation of the results, which could ultimately lead to a misinterpretation of the impact of lockdowns on the electricity consumption.

\subsection{Methodology}

\subsubsection{Comparative Analysis}

As mentioned, the data were collected in hourly resolution for each hour in 2019 and 2020. For the sake of other analyses, the dataset was arranged into daily, weekly, and monthly values. In the comparative analyses, it was decided to adjust the values of 2020 for one day. Thus, working days and days off overlapped to enable the comparison of daily differences in consumption volumes. The conducted analysis focused on differences in consumed energy volumes in hourly, daily, weekly, and monthly intervals in 2 subsequent years: in 2019, without restrictions associated with the COVID-19 pandemic; and 2020, during the pandemic.

Furthermore, the article analyzed energy demand profiles in 3 key groups of consumers. They were consistent with the Polish Classification of Activity, i.e., the set of the types of socio-economic activities undertaken by economic entities. The analyzed sections included: manufacturing (Section C), electricity, gas, steam, and air conditioning supply (Section D), and real estate activities, including the operation of shopping malls (Section L) [47].

\subsubsection{Coefficient of Variation}

This part analyzed the daily and weekly values of consumed energy. Volatility analysis was employed for investigating total consumption values. The analyses used weekly intervals (the subsequent weeks of the analyzed years), a selected working day (Tuesday), and one of the days off (Saturday). In the subsequent weeks, after computing mean and standard deviation values, total volatility was estimated for the selected variables in 2019 and 2020. 
The measure of volatility was the coefficient of variation defined as the ratio of volatility absolute measure to mean values. Most often, it is the ratio of a mean analyzed value to the value of mean standard deviation [48].

$$
V=\frac{S}{M} \cdot 100 \%
$$

where $V$-coefficient of variation, $S$-standard deviation (from the sample), $M-$ mean (from the sample).

The coefficient of variation indicates a degree of differentiation of the analyzed sample (sample's features). Depending on the results, one can conclude about the level of volatility, but this coefficient is a relative measure. It is commonly recognized that a coefficient of variation lower than $10 \%$ indicates the statistical insignificance of the tested relation [49].

\subsubsection{Forecast (Trend) and Difference Calculation}

The last stage of the analysis was to compute a difference between energy consumed in subsequent weeks and the expected values of consumption. The latter was estimated using simple regression (linear regression) based on weekly values of consumption in the 4 weeks before introducing the first and second waves of restrictions. The analyzed period included both lockdowns.

\section{Results}

This section presents the results of the analysis of energy consumption by the business clients of the studied trading and sales companies in 2019 and 2020. Tables and charts highlight differences in the values of consumed energy in the annual perspective and in detail for the lockdowns. Additionally, the consumption volumes in three sections representing the key groups of consumers were analyzed. The following parts present the volatility analysis' results with the coefficients of variation estimated in the quarterly and yearly scales. Finally, after employing linear regression, there was estimated a trend of weekly energy consumption volume during the lockdowns based on the collected data.

Figure 3 presents the comparison of electricity consumption volumes in 2019 and 2020. The blue line marked consumption volumes in the hourly resolution in 2019; the red line represents values for 2020. The differences (only positive values, indicating lower energy consumption volumes in 2020) between volumes for 2019 and 2020 were presented as a black line. The mean hourly consumption volume for the whole of 2020 was 2 MWh higher, but during the lockdowns, the mean consumption was 14 MWh and 1 MWh lower in the first and second lockdown, respectively (Figures 4 and 5).

The confirmation of a significant decrease in the volume of energy consumption in the first lockdown is also visible in the analysis of total consumption for individual months (Figure 6). The first restrictions announced on 14 March 2020, caused a change of the expected increase in the energy consumption trend, observed before, e.g., in February. The following months of the first lockdown have brought additional declines. Compared with 2019, they were 13\% in April and 4\% in May when the strictest limitations were lifted. In June, the consumption volume was similar to the previous year. A significant increase in the consumption volume could be observed in the third quarter in the absolute values and relation to the same period in 2019. Another drop overlaps with the second wave of introducing severe restrictions. In October, the year-on-year value was even higher, even though the increasing energy consumption trend of 2019 was not maintained. In November 2020, the energy consumption was 1\% lower than in the previous year, and the downward trend became clearly visible. The lifting of Another restriction (27 November) definitely impacted the consumption increase in December. 


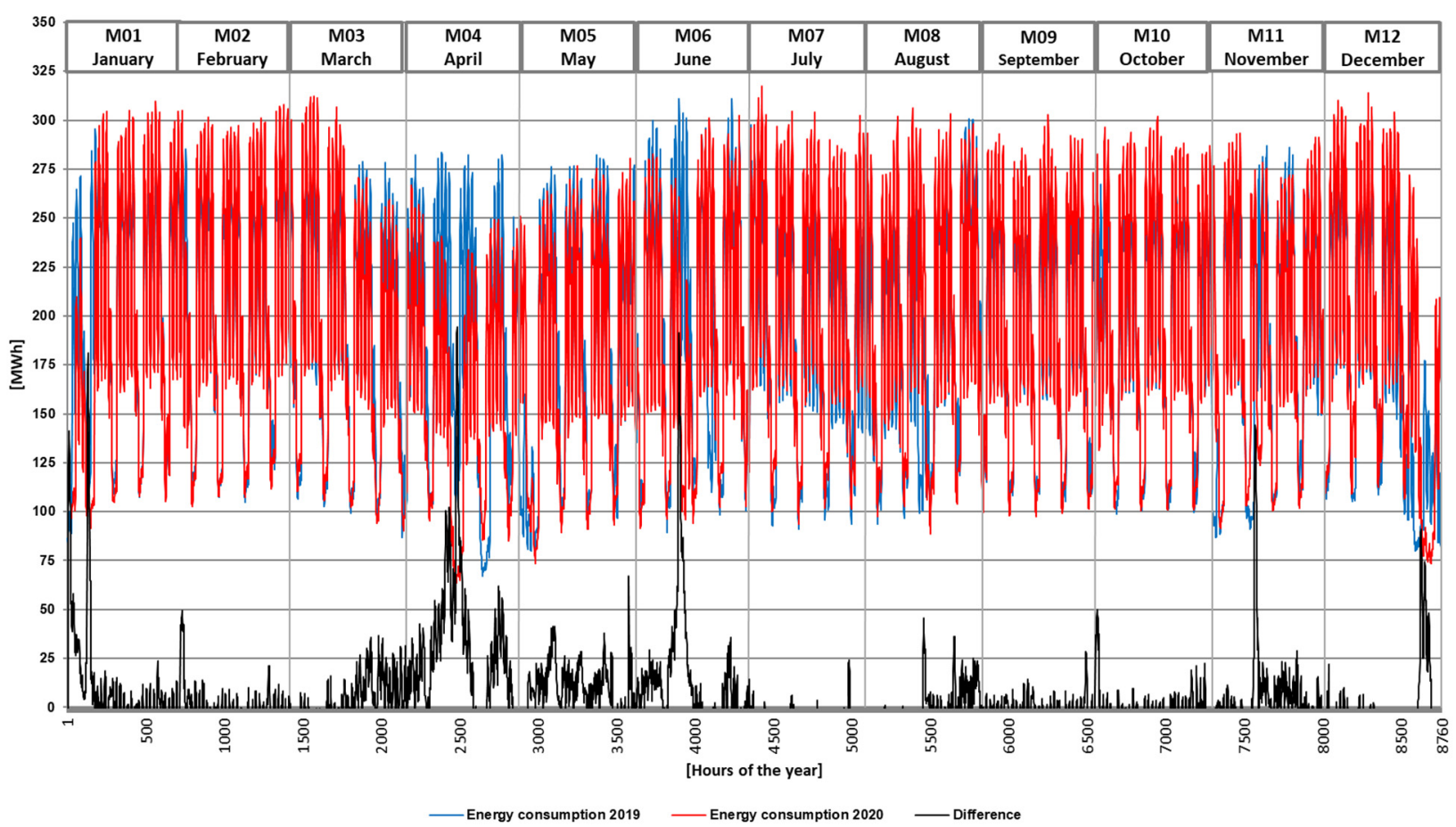

Figure 3. Comparative analysis of energy consumption in 2019-2020.

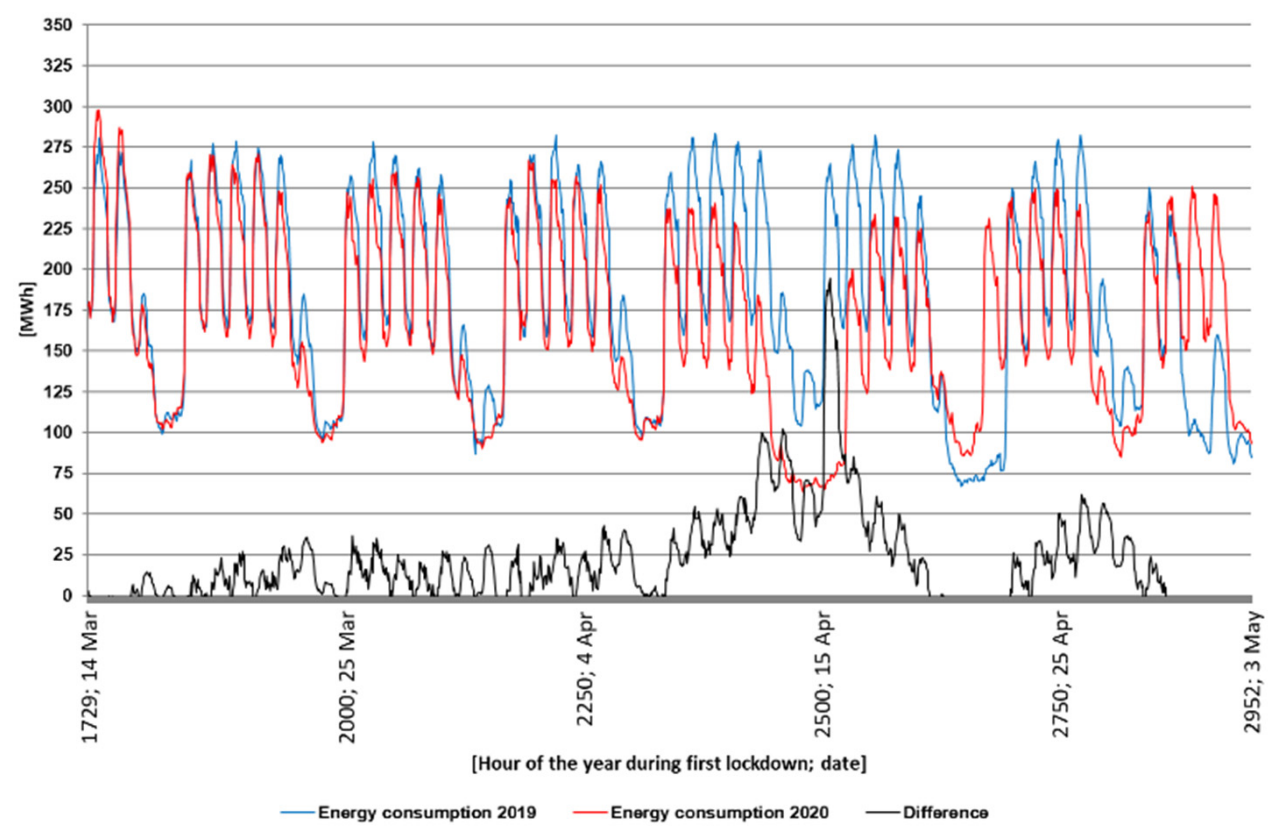

Figure 4. Comparative analysis of energy consumption 14 March-3 May (the first lockdown). 


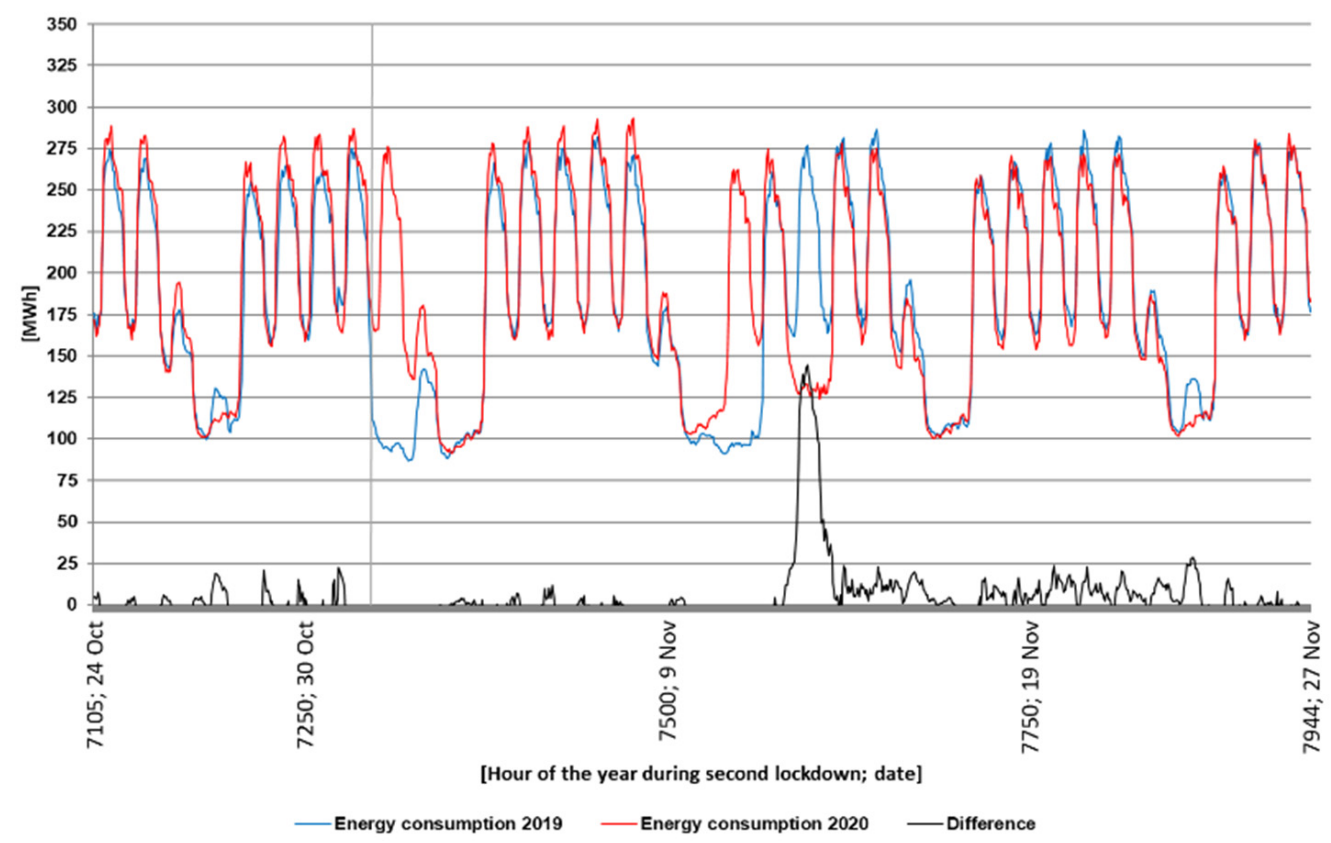

Figure 5. Comparative analysis of energy consumption 24 October-27 November (the second lockdown).

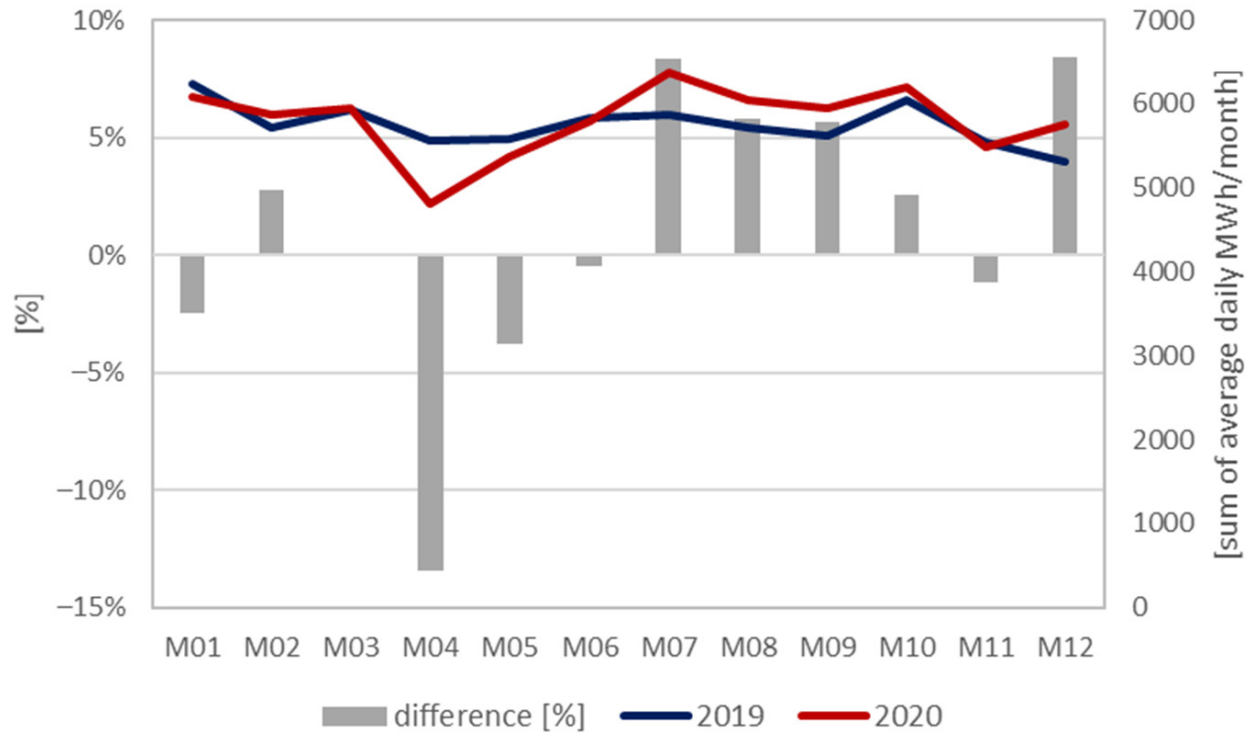

Figure 6. Comparison of energy consumption in 2019 and 2020 (difference 2019-2020).

Charts in Figure 7 present weekly electricity consumption profiles (W-week) in the groups of trading and sales company's key clients during the first and second lockdowns. The dashed line marks the period without restrictions (W10-11) and (W42-43) while the solid line the lockdown periods (W13-W18) and (W44-W48). The consumption values for the weeks W16, W18, and W46 are distorted because of the official days off, Easter Days (12-13 April), Labor Day, and 3 May Constitution Day (1-3 May), also Polish Independence Day (11 November). 

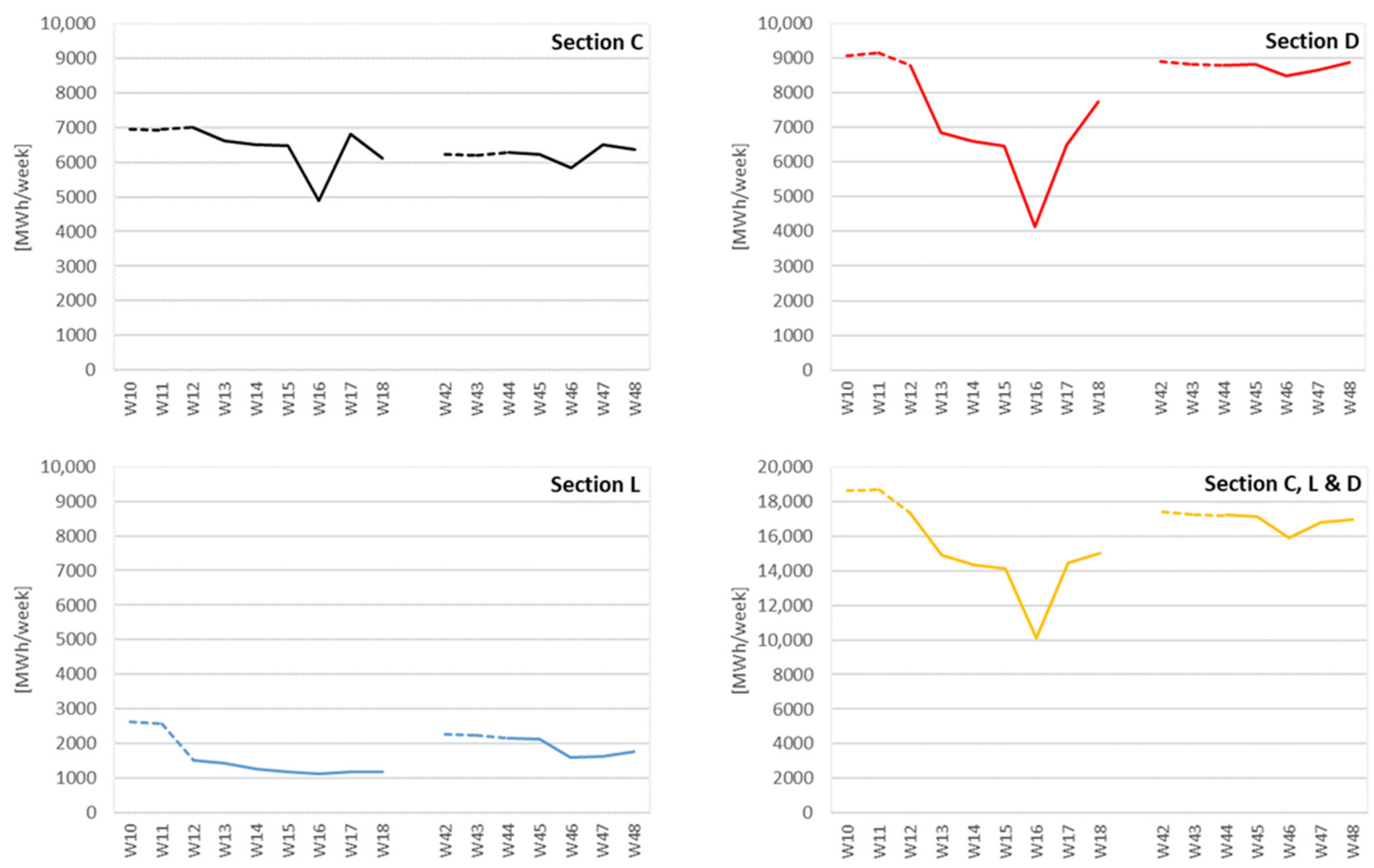

Figure 7. Weekly profiles of energy consumption for key sectors.

The analysis indicates that during the lockdown, the consumption volumes of Section $C$ clients (manufacturing) have not changed drastically, but the volume decline was visible (400 MWh in the first week and $600 \mathrm{MWh} /$ week in two others). The second lockdown did not significantly reflect on the volume of energy consumed by clients belonging to this section. Furthermore, during the lockdowns, for Section D clients (electricity, gas, steam, and air for air-conditioning supply), the energy consumption decrease was significant (400 MWh in the first week and more than $2000 \mathrm{MWh}$ /week in the other three). However, the second lockdown did not impact the consumption value as much as the previous one. Besides trading real estates, Section L entities also service trading-office-entertainment complexes (shopping malls), which was clearly reflected in the electricity consumption volumes during the lockdowns. Yet, in the first lockdown, the volume of consumed energy decreased by 1000-1300 MWh per week, which was ca. 50\% of the total decline in that group. In the second lockdown, there is clearly visible the second wave of restrictions (associated with the limitations imposed on shopping malls), in the period W46-W48, the consumption volumes were decreasing by ca. 500 MWh per week.

Another step was conducting the volatility analysis. The tables demonstrate the computed coefficients of variation for energy consumed by the clients. They are supplemented by standard deviation and mean values. The tables include the calculations of energy consumption volumes for weeks (Table 1), a selected working day, Tuesday (Table 2), and a selected day off, Saturday (Table 3). In all cases, the volatility of consumption volumes in 2020 did not change significantly compared to 2019. However, the noticeable changes in total values were related to the pandemic limitations. 
Table 1. Results of volatility analysis—coefficients of variation (Energy consumption—week).

\begin{tabular}{|c|c|c|c|c|c|c|c|}
\hline \multicolumn{2}{|c|}{ Parameter } & Unit & Year & IQ & IIQ & IIIQ & IVQ \\
\hline \multirow{3}{*}{$\begin{array}{l}\text { Energy consumption-week } \\
\qquad(2019)\end{array}$} & Mean & [MWh/week] & 31,775 & 33,590 & 31,383 & 31,340 & 30,788 \\
\hline & Standard deviation & [MWh/week] & 3031 & 1157 & 3613 & 1873 & 4112 \\
\hline & Coefficient of variation & {$[\%]$} & $10 \%$ & $3 \%$ & $12 \%$ & $6 \%$ & $13 \%$ \\
\hline \multirow{3}{*}{$\begin{array}{l}\text { Energy consumption-week } \\
\qquad(2020)\end{array}$} & Mean & [MWh/week] & 32,125 & 33,001 & 29,484 & 33,558 & 32,459 \\
\hline & Standard deviation & [MWh/week] & 3435 & 3306 & 3566 & 758 & 4023 \\
\hline & Coefficient of variation & [\%] & $11 \%$ & $10 \%$ & $12 \%$ & $2 \%$ & $12 \%$ \\
\hline
\end{tabular}

Table 2. Results of volatility analysis—coefficients of variation (Energy consumption—a working day).

\begin{tabular}{|c|c|c|c|c|c|c|c|}
\hline \multicolumn{2}{|c|}{ Parameter } & \multirow{2}{*}{$\frac{\text { Unit }}{\text { [MWh/week] }}$} & \multirow{2}{*}{$\begin{array}{l}\text { Year } \\
5313\end{array}$} & \multirow{2}{*}{$\frac{\text { IQ }}{5565}$} & \multirow{2}{*}{$\begin{array}{c}\text { IIQ } \\
5267\end{array}$} & \multirow{2}{*}{$\begin{array}{l}\text { IIIQ } \\
5140\end{array}$} & \multirow{2}{*}{$\begin{array}{l}\text { IVQ } \\
5296\end{array}$} \\
\hline Energy & Mean & & & & & & \\
\hline \multirow{2}{*}{$\begin{array}{l}\text { consumption-working day } \\
\text { (Tuesday 2019) }\end{array}$} & Standard deviation & [MWh/week] & 324 & 111 & 435 & 317 & 203 \\
\hline & Coefficient of variation & [\%] & $6 \%$ & $2 \%$ & $8 \%$ & $6 \%$ & $4 \%$ \\
\hline \multirow{3}{*}{$\begin{array}{c}\text { Energy } \\
\text { consumption-working day } \\
\text { (Tuesday 2020) }\end{array}$} & Mean & [MWh/week] & 5328 & 5526 & 4995 & 5474 & 5320 \\
\hline & Standard deviation & [MWh/week] & 446 & 334 & 536 & 161 & 500 \\
\hline & Coefficient of variation & {$[\%]$} & $8 \%$ & $6 \%$ & $11 \%$ & $3 \%$ & $9 \%$ \\
\hline
\end{tabular}

Table 3. Results of volatility analysis—coefficients of variation (Energy consumption—a day off).

\begin{tabular}{|c|c|c|c|c|c|c|c|}
\hline Parame & & Unit & Year & IQ & IIQ & IIIQ & IVQ \\
\hline \multirow{3}{*}{$\begin{array}{l}\text { Energy consumption-day off } \\
\text { (Saturday 2019) }\end{array}$} & Mean & [MWh/week] & 3712 & 3841 & 3636 & 3722 & 3650 \\
\hline & Standard deviation & [MWh/week] & 348 & 211 & 522 & 262 & 364 \\
\hline & Coefficient of variation & [\%] & $9 \%$ & $5 \%$ & $14 \%$ & $7 \%$ & $10 \%$ \\
\hline \multirow{3}{*}{$\begin{array}{l}\text { Energy consumption-day off } \\
\text { (Saturday 2020) }\end{array}$} & Mean & [MWh/week] & 3648 & 3868 & 3143 & 3756 & 3842 \\
\hline & Standard deviation & [MWh/week] & 454 & 298 & 521 & 297 & 182 \\
\hline & Coefficient of variation & {$[\%]$} & $12 \%$ & $8 \%$ & $17 \%$ & $8 \%$ & $5 \%$ \\
\hline
\end{tabular}

The volatility analysis for weekly electricity consumption values (Table 1) shows that the variation in the whole year was insignificantly higher. In the analysis of shorter (quarterly) intervals, it increased significantly only in the first quarter (from 3\% to 10\%), which could be caused by introducing the first restrictions at the end of the quarter. Despite the lockdowns, in the second and fourth quarters, the variation in 2019 and 2020 was ca. $12 \%$. It was influenced by the restrictions and periods with the expected total change in energy consumption values (Easter, May weekend, II quarter, All Saints' Day, and Christmas, IV quarter).

In the case of energy consumption values for a selected working day, Tuesday (Table 2), the analysis indicates a minimal increase of volatility in the yearly scale (from $6 \%$ to $8 \%$ ) and individual quarters with the restrictions. In the first quarter it increased from $2 \%$ to $6 \%$, in the second from $8 \%$ to $11 \%$, and in the fourth from $4 \%$ to $9 \%$, respectively. 1 January 2019 (New Year) was a day off, which is why the analysis omits the consumption values for that date.

The volatility analysis of energy consumption in the selected day off, Saturday (Table 3), indicates that in 2020, the variation was insignificantly higher than in 2019. Unlike for the values for working days, the higher variability of electricity consumption could be observed in the first, second, and third quarters. 
Tables 4 and 5, Figures 8 and 9, present the analysis of weekly energy consumption volumes during the first and second lockdowns in relation to the trend outlined based on four weeks before introducing restrictions.

In the first lockdown, decreases of the actual electricity consumption compared to expected values were large. Only at the first stage of implementing restrictions (since $14 \mathrm{March}$ ), the decrease of consumption in the subsequent weeks was $11 \%, 16 \%$, and $15 \%$. The consequences of limiting commerce, closing shopping malls, and restrictions imposed on industry were tangible. After introducing new restrictions (1 April), one could observe an additional decrease in the weekly energy consumption values. However, the following weeks of the first lockdown could not be analyzed in detail because of the Easter holidays (21-22 April 2019 and 12-13 April 2020).

The second lockdown analysis concerned the five restricted weeks. During that period, there was no limitation on movement and entire suspending services and commerce. The differences to the appointed trend were $2 \%, 2 \%, 11 \%, 6 \%$, and $2 \%$ in subsequent weeks. The second wave of restrictions is clearly marked by the moment of closing shopping malls (from W46). As in the first lockdown, the difference to the appointed trend in the first week of the restrictions was $11 \%$. However, actual energy consumption values were lower than expected.

Table 4. Analysis of energy consumption in relation to the forecast trend (the first lockdown).

\begin{tabular}{|c|c|c|c|c|c|c|}
\hline \multirow{2}{*}{\multicolumn{2}{|c|}{ Number of Week }} & \multirow[t]{2}{*}{ Date } & \multirow{2}{*}{$\begin{array}{c}\text { Energy } \\
\text { Consumption }\end{array}$} & \multirow{2}{*}{$\begin{array}{l}\text { Values Calculated in Line } \\
\text { with (W8-W11) Trend }\end{array}$} & \multicolumn{2}{|c|}{$\begin{array}{l}\text { The Difference Value in } \\
\text { Reference to the Trend }\end{array}$} \\
\hline & & & & & Volume & $\%$ \\
\hline$[-]$ & & {$[-]$} & [MWh/week] & [MWh/week] & [MWh/week] & {$[\%]$} \\
\hline \multirow{4}{*}{$\begin{array}{c}\mathrm{NO} \\
\text { LOCKDOWN }\end{array}$} & W8 & 15-21 February 2020 & 35,051 & 35,051 & 0 & $0 \%$ \\
\hline & W9 & 22-28 February 2020 & 36,060 & 36,060 & 0 & $0 \%$ \\
\hline & W10 & 29 February-6 March 2020 & 36,169 & 36,170 & 0 & $0 \%$ \\
\hline & W11 & 7-13 March 2020 & 34,689 & 34,688 & 0 & $0 \%$ \\
\hline \multirow{4}{*}{ LOCKDOWN } & W12 & 14-20 March 2020 & 31,407 & 35,345 & 3938 & $-11 \%$ \\
\hline & W13 & 21-27 March 2020 & 29,432 & 35,247 & 5816 & $-16 \%$ \\
\hline & W14 & 28 March-3 April 2020 & 29,832 & 35,150 & 5318 & $-15 \%$ \\
\hline & W15 & 4-10 April 2020 & 26,995 & 35,052 & 8057 & $-23 \%$ \\
\hline
\end{tabular}

Table 5. Analysis of energy consumption in relation to the forecast trend (the second lockdown).

\begin{tabular}{|c|c|c|c|c|c|c|}
\hline \multirow{2}{*}{\multicolumn{2}{|c|}{ Number of Week }} & \multirow{2}{*}{ Date } & \multirow{2}{*}{$\begin{array}{c}\text { Energy } \\
\text { Consumption }\end{array}$} & \multirow{2}{*}{$\begin{array}{l}\text { Values Calculated in Line } \\
\text { with (W40-W43) Trend }\end{array}$} & \multicolumn{2}{|c|}{$\begin{array}{l}\text { The Difference Value in } \\
\text { Reference to the Trend }\end{array}$} \\
\hline & & & & & Volume & $\%$ \\
\hline$[-]$ & & {$[-]$} & [MWh/week] & [MWh/week] & [MWh/week] & [\%] \\
\hline \multirow{4}{*}{$\begin{array}{c}\text { NO } \\
\text { LOCKDOWN }\end{array}$} & W40 & 26 September-2 October 2020 & 33,400 & 33,400 & 0 & $0 \%$ \\
\hline & W41 & 3-09 October 2020 & 33,527 & 33,527 & 0 & $0 \%$ \\
\hline & W42 & 10-16 October 2020 & 33,995 & 33,995 & 0 & $0 \%$ \\
\hline & W43 & 17-23 October 2020 & 33,465 & 33,465 & 0 & $0 \%$ \\
\hline \multirow{5}{*}{ LOCKDOWN } & W44 & 24-30 October 2020 & 33,126 & 33,763 & 637 & $-2 \%$ \\
\hline & W45 & 31 October-6 November 2020 & 33,127 & 33,829 & 702 & $-2 \%$ \\
\hline & W46 & 7-13 November 2020 & 30,040 & 33,896 & 3856 & $-11 \%$ \\
\hline & W47 & 14-20 November 2020 & 31,772 & 33,962 & 2190 & $-6 \%$ \\
\hline & W48 & 21-27 November 2020 & 33,312 & 34,029 & 717 & $-2 \%$ \\
\hline
\end{tabular}




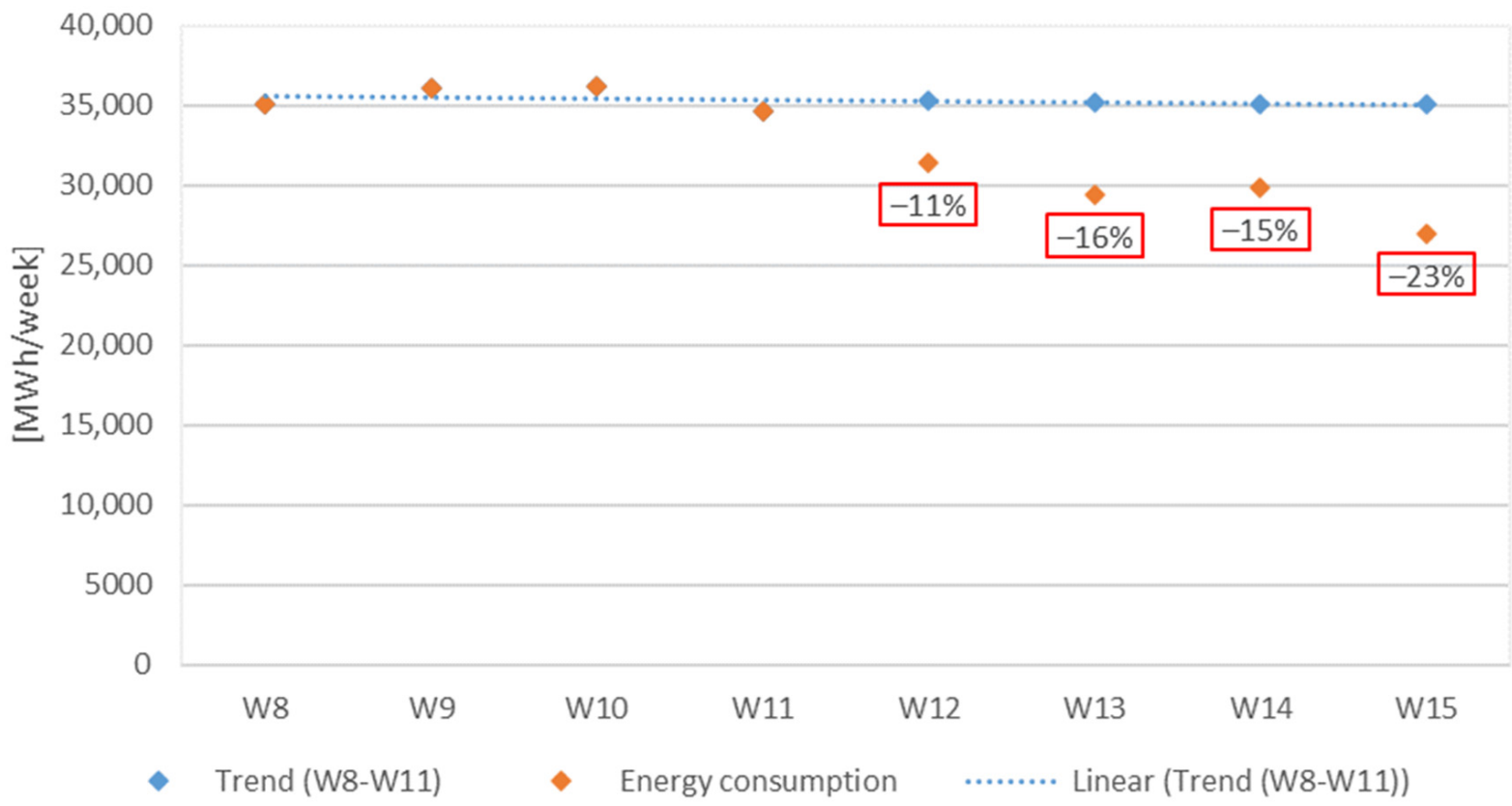

Figure 8. Analysis of energy consumption in relation to the forecast trend (the first lockdown).

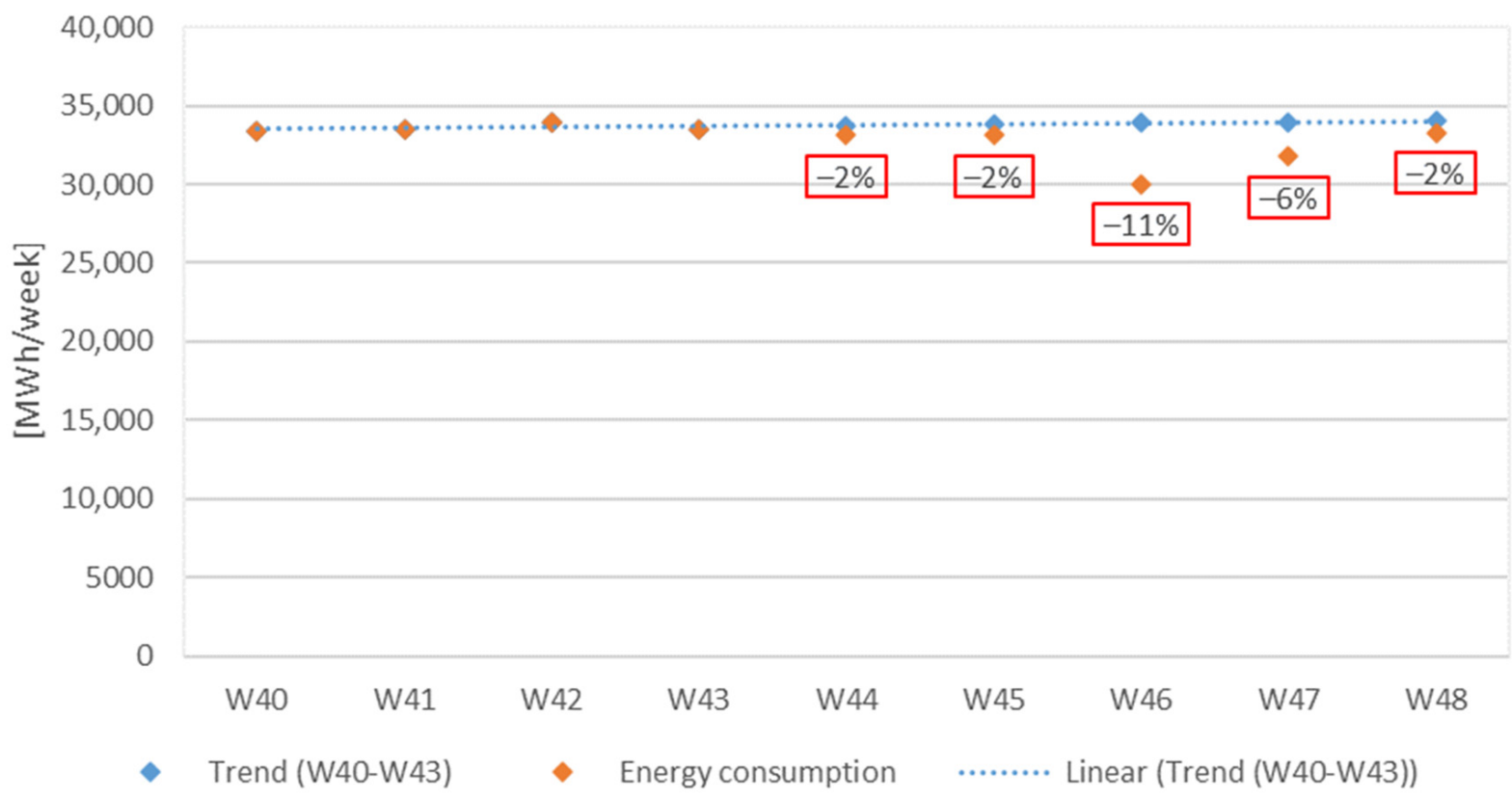

Figure 9. Analysis of energy consumption in relation to the forecast trend (the second lockdown).

\section{Conclusions}

The analysis confirmed an evident decline in energy consumption volumes during the lockdowns compared to values for 2019 and from several weeks before introducing new limitations. The changes are evident in the first stage of the pandemic. Beyond the lockdowns, energy consumption volumes in 2020 were several percent higher than in 2019.

The analysis of electricity consumption volumes of the key clients from the manufacturing and electricity, gas, steam, and air conditioning supply sections showed that the values were significantly lower only during the first lockdown while in the section real estate activities, each restriction related to closing shopping malls caused noticeable changes in energy consumption.

Restrictions imposed on the functioning of shopping malls cause a substantial decrease in the volumes of consumed energy in the analyzed group of clients, although 
the total value of their consumption is only ca. $15 \%$. Moreover, energy demand profiles reflect additional limitations related to movement, commerce, and services (the so-called beauty industry).

To summarize, the restrictions caused a 15-23\% decline in energy consumption during the first lockdown and a maximum of $11 \%$ during the second, against expected values. The conducted analysis demonstrates that in the context of the decline, the most significant aspect for the investigated group of clients was the limitation of commerce (including the closing of shopping malls). That and other restrictive regulations caused a ca. 9-11\% decrease in energy consumption against the expected value in both periods of restrictions. The results should be verified based on data from lockdowns introduced in 2021.

The analysis demonstrates that additional restrictions (ban of movement, limiting commerce, and services) cause a higher drop in consumed energy volumes. The collected data are insufficient for concluding about exact values because some limitations were employed only one time.

The second lockdown caused changes in energy consumption profiles in the analyzed group of clients. Undoubtedly, it was impacted by the type of restrictions. During the second lockdown, there were no limitations on movement and no entire closing of commerce and services. Moreover, safety protocols used by industries have not entailed the necessity for limiting or canceling production.

The conducted volatility analysis proved that consumption volumes in $2020 \mathrm{did}$ not change dramatically compared with 2019. However, the temporal increase of the coefficient of variation during the lockdowns was observed. The impact was seen particularly in analyzing energy consumption on a typical working day (Tuesday) for the first, second, and fourth quarter of the year and a day off (Saturday) for the first and second quarters.

The results are adequate to an energy trading and sales company having in its portfolio client groups mentioned in the paper (industry, services, commerce). It is possible that the implemented restrictions influenced various business activities differently. That observation justifies the need for conducting detailed analyses of the restrictions' impact on energy consumption in different branches of the economy.

The conducted research and further detailed analyses are required to improve the methods of forecasting customer energy consumption. Due to the dynamically changing electricity prices, the accurate forecasting of energy volumes significantly impacts the finances of energy trading and sales companies.

Author Contributions: Conceptualization, M.M., G.K. and M.C.; methodology, M.M., G.K. and M.C.; software, M.M.; validation, M.M.; investigation, M.M., G.K. and M.C.; resources, M.M. and M.C.; data curation, M.M. and G.K.; writing—original draft preparation, M.M., G.K. and M.C.; writing—review and editing, M.M., G.K. and M.C.; visualization, M.M. and G.K.; supervision, G.K. and M.C. All authors have read and agreed to the published version of the manuscript.

Funding: The publication has been financed using a subsidy for maintenance and development of research potential and received no external funding.

Acknowledgments: The work was carried out as part of the statutory activity of the Mineral and Energy Economy Research Institute, Polish Academy of Sciences and WSB University.

Conflicts of Interest: The authors declare no conflict of interest.

\section{References}

1. Electricity Market Report; International Energy Agency (IEA): Paris, France, 2020. Available online: https://www.iea.org/reports/ electricity-market-report-december-2020 (accessed on 21 May 2021).

2. Nikola, M.; Alsafi, Z.; Sohrabi, C.; Kerwan, A.; Al-Jabir, A.; Iosifidis, C.; Agha, M.; Agha, R. The socio-economic implications of the coronavirus pandemic (COVID-19): A review. Int. J. Surg. 2020, 78, 185-193. [CrossRef]

3. Szczepańska-Woszczyna, K. Management Theory, Innovation, and Organisation: A Model of Managerial Competencies; Routledge: Oxfordshire, UK, 2020; p. 206.

4. Kinelski, G. The main factors of successful project management in the aspect of energy enterprises' efficiency in the digital economy environment. Polityka Energetyczna Energy Policy J. 2020, 23, 5-20. [CrossRef] 
5. COVID-19 Impact on Electricity; International Energy Agency (IEA): Paris, France, 2020. Available online: https://www.iea.org/ reports/covid-19-impact-on-electricity (accessed on 20 May 2021).

6. Crider, J. COVID-19 Bankrupts 19 Energy (Oil \& Gas) Companies. 2020. Available online: https://cleantechnica.com/2020/08/ 05/covid-19-bankrupts-19-energy-oil-gas-companies (accessed on 20 May 2021).

7. Baker, M.G.; Wilson, N.; Blakely, T. Elimination could be the optimal response strategy for covid-19 and other emerging pandemic diseases. BMJ 2020, 371. [CrossRef]

8. Czosnyka, M.; Wnukowska, B.; Karbowa, K. Electrical energy consumption and the energy market in Poland during the COVID-19 pandemic. In 2020 Progress in Applied Electrical Engineering (PAEE); IEEE: Piscataway, NJ, USA, 2020; pp. 1-5. [CrossRef]

9. Polish Power System-PSE-Reports. Available online: https://www.pse.pl/web/pse-eng/data (accessed on 12 May 2021).

10. Kaźmierska, M. Zużycie Prądu w Polsce. Jaki Wpływ Lockdownu? 2020. Available online: www.enerad.pl (accessed on 3 February 2021). (In Polish).

11. Saługa, P.W.; Szczepańska-Woszczyna, K.; Miśkiewicz, R.; Chłąd, M. Cost of Equity of Coal-Fired Power Generation Projects in Poland: Its Importance for the Management of Decision-Making Process. Energies 2020, 13, 4833. [CrossRef]

12. Mucha-Kuś, K.; Sołtysik, M.; Zamasz, K.; Szczepańska-Woszczyna, K. Coopetitive Nature of Energy Communities-The Energy Transition Context. Energies 2021, 14, 931. [CrossRef]

13. Kinelski, G. Two-way market and the existence of its competitiveness in the electrolygenic subsector. Rynek dwutowarowy i istota jego konkurencyjności w sektorze elektroenergetycznym. Zesz. Nauk. Inst. Gospod. Surowcami Miner. I Energia Pol. Akad. Nauk. 2018, 102, 277-299. (In Polish)

14. Wójcik-Jurkiewicz, M.; Czarnecka, M.; Kinelski, G.; Sadowska, B.; Bilińska-Reformat, K. Determinants of Decarbonisation in the Transformation of the Energy Sector: The Case of Poland. Energies 2021, 14, 1217. [CrossRef]

15. Łabinowicz, K.; Bujalski, W. Extracting main factors influencing spot electricity prices with application of statistical methods. Wyodrębnienie głównych czynników kształtujących ceny energii elektrycznej na Rynku Dnia Następnego z wykorzystaniem metod statystycznych. Rynek Energii 2015, 6, 15-21. (In Polish)

16. Malec, M. Impact of the volatility of coal prices in the international markets and it's impact on the volatility of domestic fuel and electricity prices. Wpływ zmienności cen węgla kamiennego na rynkach światowych na zmienność cen paliw i energii elektrycznej w Polsce. Polityka Energetyczna Energy Policy J. 2017, 4, 39-54. (In Polish)

17. Nowotarski, J.; Weron, R. Recent advances in electricity price forecasting: A review of probabilistic forecasting. Renew. Sustain. Energy Rev. 2018, 81, 1548-1568. [CrossRef]

18. Maciejowska, K.; Nitka, W.; Weron, T. Day-ahead vs. Intraday-Forecasting the price spread to maximize economic benefits. Energies 2019, 12, 631. [CrossRef]

19. Edoli, E.; Fiorenzani, S.; Vargiolu, T. Optimal Trading Strategies in Intraday Power Markets. In Optimization Methods for Gas and Power Markets; Palgrave Macmillan: London, UK, 2016; pp. 161-184. [CrossRef]

20. Ghenai, C.; Bettayeb, M. Data analysis of the electricity generation mix for clean energy transition during COVID-19 lockdowns. Energy Sources Part A Recover. Util. Environ. Eff. 2021, 43. [CrossRef]

21. Zhong, H. Implications of COVID-19 for the Electricity Industry: A Comprehensive Review. CSEE J. Power Energy Syst. 2020, 6, 489-495. [CrossRef]

22. Fezzi, C. Real-Time Estimation of the Short-Run Impact of COVID-19 on Economic Activity Using Electricity Market Data. Environ. Resour. Econ. 2020, 76, 885-900. [CrossRef] [PubMed]

23. Benatia, D.; Feron, O.; Alasseur, C. Ring the Alarm! Electricity Markets, Renewables, and the Pandemic; USAEE Working Paper No. 20-473; USAEE: Dayton, OH, USA, 2020. Available online: https:/ / ssrn.com/abstract=3703117 (accessed on 10 May 2021).

24. Mirnezami, S.R.; Rajabi, S. Changing primary energy consumption due to covid-19: The study 20 european economies. Int. J. Energy Econ. Policy 2021, 11, 615-631. [CrossRef]

25. Castan Broto, V.; Kirshner, J. Energy access is needed to maintain health during pandemics. Nat. Energy 2020, 5, 419-421. [CrossRef]

26. Elavarasan, R.M.; Shafiullah, G.M.; Kannadasan, R.; Mudgal, V.; Arif, M.T.; Jamal, T. COVID-19: Impact analysis and recommendations for power sector operation. Appl. Energy 2020, 279, 115739. [CrossRef]

27. Global Energy Review 2020: The Impacts of the COVID-19 Crisis on Global Energy Demand and $\mathrm{CO}_{2}$ Emissions; International Energy Agency (IEA): Paris, France, 2020. Available online: https://www.iea.org/reports/global-energy-review-2020 (accessed on 22 May 2021).

28. Abu-Rayash, A.; Dincer, I. Analysis of the electricity demand trends amidst the COVID-19 coronavirus pandemic. Energy Res. Soc. Sci. 2020, 68, 101682. [CrossRef]

29. Chen, C.F.; de Rubens, G.Z.; Xu, X.; Li, J. Coronavirus comes home? Energy use, home energy management, and the socialpsychological factors of COVID-19. Energy Res. Soc. Sci. 2020, 68, 101682. [CrossRef]

30. Sui, Y.; Zhang, H.; Shang, W.; Sun, R.; Wang, C.; Ji, J. Mining urban sustainable performance: Spatio-temporal emission potential changes of urban transit buses in post-COVID-19 future. Appl. Energy 2020, 280, 115966. [CrossRef]

31. Bielecki, S.; Skoczkowski, T.; Sobczak, L.; Buchoski, J.; Maciag, Ł.; Dukat, P. Impact of the Lockdown during the COVID-19 Pandemic on Electricity Use by Residential Users. Energies 2021, 14, 980. [CrossRef]

32. Cheshmehzangi, A. COVID-19 and household energy implications: What are the main impacts on energy use? Heliyon 2020, 6, e05202. [CrossRef] 
33. Santiago, I.; Moreno-Munoz, A.; Quintero-Jiménez, P.; Garcia-Torres, F.; Gonzalez-Redondo, M.J. Electricity demand during pandemic times: The case of the COVID-19 in Spain. Energy Policy 2021, 148, 111964. [CrossRef]

34. Rouleau, J.; Gosselin, L. Impacts of the COVID-19 lockdown on energy consumption in a Canadian social housing building. Appl. Energy 2021, 287, 116565. [CrossRef]

35. Jiang, P.; Klemeš, J.J.; Bee, Y.M. More is not enough: A deeper understanding of the covid-19 impacts on healthcare, energy and environment is crucial. Int. J. Environ. Res. Public Health 2021, 18, 684. [CrossRef]

36. Jiang, P.; Fan, Y.V.; Klemeš, J.J. Impacts of COVID-19 on energy demand and consumption: Challenges, lessons and emerging opportunities. Appl. Energy 2021, 18, 684. [CrossRef]

37. Eurostat Report-Impact of COVID-19 Crisis on Short-Term Statistics. 2021. Available online: https:/ / ec.europa.eu/eurostat/ statistics-explained/index.php?title=Impact_of_Covid-19_crisis_on_short-term_statistics (accessed on 30 May 2021).

38. European Parliament Report-Impacts of the COVID-19 Pandemic on EU Industries. 2021. Available online: https://www. europarl.europa.eu/ (accessed on 2 June 2021).

39. Bompard, E.; Mosca, C.; Colella, P.; Antonopoulos, G.; Fulli, G.; Masera, M.; Poncela-Blanco, M.; Vitiello, S. The Immediate Impacts of COVID-19 on European Electricity Systems: A First Assessment and Lessons Learned. Energies 2021, 14, 96. [CrossRef]

40. Fu, M.; Shen, H. COVID-19 and Corporate Performance in the Energy Industry. Energy Res. Lett. 2020, 1, 12967. [CrossRef]

41. Graf, C.; Quaglia, F.; Wolak, F.A. (Machine) learning from the COVID-19 Lockdown about Electricity Market Performance with a large share of renewables. J. Environ. Econ. Manag. 2021, 105, 102398. [CrossRef]

42. Kuzemko, C.; Bradshaw, M.; Bridge, G.; Goldthau, A.; Jewell, J.; Overland, I.; Scholten, D.; Van de Graaf, T.; Westphal, K. COVID-19 and the politics of sustainable energy transitions. Energy Res. Soc. Sci. 2020, 68, 101685. [CrossRef] [PubMed]

43. Aruga, K.; Islam, M.; Jannat, A. Effects of COVID-19 on Indian energy consumption. Sustainability 2020, 12, 5616. [CrossRef]

44. Gomez-Omella, M.; Esnaola-Gonzalez, I.; Ferreiro, S. Short-Term Forecasting Methodology for Energy Demand in Residential Buildings and the Impact of the COVID-19 Pandemic on Forecasts. In International Conference on Innovative Techniques and Applications of Artificial Intelligence; Bramer, M., Ellis, R., Eds.; Springer: Cham, Switzerland, 2020. [CrossRef]

45. Alasali, F.; Nusair, K.; Alhmoud, L.; Zarour, E. Impact of the COVID-19 Pandemic on Electricity Demand and Load Forecasting. Sustainability 2021, 13, 1435. [CrossRef]

46. COVID-19 in Poland. Governments Actions. Available online: https://www.gov.pl/web/koronawirus/dzialania-rzadu (accessed on 22 April 2021). (In Polish)

47. Code List of Classification of Business Activities in Poland (PKD Classification). Available online: https://ec.europa.eu/eurostat/ ramon/nomenclatures/index.cfm?TargetUrl=LST_NOM_DTL\&StrNom=NACE_REV2\&StrLanguageCode=EN\&IntPcKey= \&StrLayoutCode=HIERARCHIC\&IntCurrentPage=1 (accessed on 1 June 2021).

48. Subrahmanya Nairy, K.; Aruna Rao, K. Tests of Coefficients of Variation of Normal Population. Commun. Stat. Simul. Comput. 2003, 32, 641-661. [CrossRef]

49. Forkman, J. Estimator and Tests for Common Coefficients of Variation in Normal Distributions. Commun. Stat. Theory Methods 2009, 38, 233-251. [CrossRef] 